\title{
Paracaesicola nanshaensis n. gen., n. sp. (Monogenea, Microcotylidae) a gill parasite of Paracaesio sordida (Teleostei, Lutjanidae) from the South China Sea
}

\author{
Zi-Hua Zhou, You-Zhi Li, Lin Liu, Xue-Juan Ding, and Kai Yuan* \\ Guangdong Provincial Key Laboratory for Healthy and Safe Aquaculture, College of Life Science, South China Normal University, \\ 510631 Guangzhou, PR China
}

Received 6 October 2019, Accepted 27 April 2020, Published online 15 May 2020

\begin{abstract}
Paracaesicola n. gen., is erected herein to accommodate a new microcotylid species, Paracaesicola nanshaensis n. sp., collected from the Yongshu Reef, South China Sea. This species is the first monogenean to be recorded from the gills of Paracaesio sordida. The new species is characterized by the following features: (i) haptor short, with clamps arranged in two equal bilateral rows; (ii) testes numerous, arranged in two roughly alternating longitudinal rows, extending into the haptor; (iii) genital atrium armed with 16 robust spines, which are vertically arranged on top of the sausage shaped muscular male copulatory organ; and (iv) single vagina, bottle-shaped, with a distinctly bulbous vaginal atrium. The terminals of the reproductive system discriminate Paracaesicola $\mathrm{n}$. gen. from all other genera in the Microcotylidae. Molecular phylogenetic analyses, based on partial 28S rDNA, places Paracaesicola nanshaensis $\mathrm{n}$. sp. within the microcotylid clade, but its sequence differs from all known available microcotylid sequences.
\end{abstract}

Key words: Monogenea, Microcotylidae, Paracaesicola nanshaensis n. gen. n. sp., Paracaesio sordida, The South China Sea.

Résumé - Paracaesicola nanshaensis n. gen., n. sp. (Monogenea, Microcotylidae), parasite branchial de Paracaesio sordida (Teleostei, Lutjanidae) de la mer de Chine méridionale. Paracaesicola n. gen. est érigé ici pour accueillir une nouvelle espèce de Microcotylidae, Paracaesicola nanshaensis n. sp., collectée sur le récif de Yongshu, mer de Chine méridionale. Cette espèce est le premier monogène signalé des branchies de Paracaesio sordida. La nouvelle espèce est caractérisée par : (i) hapteur court, avec des pinces disposées en deux rangées bilatérales égales ; (ii) testicules nombreux, disposés en deux rangées longitudinales à peu près alternées, s'étendant jusqu'au hapteur ; (iii) atrium génital armé de 16 épines robustes, disposées verticalement au-dessus de l'organe copulateur mâle, musculaire et en forme de saucisse ; et (iv) vagin unique, en forme de bouteille, avec un atrium vaginal nettement bulbeux. Les parties terminales du système reproducteur distinguent Paracaesicola n. gen. de tous les autres genres de Microcotylidae. Les analyses phylogénétiques moléculaires, basées sur l'ADNr 28S partiel, placent Paracaesicola nanshaensis n. sp. au sein du clade des Microcotylidae, mais sa séquence diffère de toutes les séquences de Microcotylidae disponibles.

\section{Introduction}

Microcotylidae Taschenberg, 1879 is the most speciose family in the Polyopisthocotylea monogeneans, and most species in this family parasitize marine teleost fishes. Tripathi [33] and Dillon \& Hargis [10] proposed early arrangements of the species in this family. Unnithan [34] proposed a taxonomic rearrangement of Microcotylidae, dividing the family into four subfamilies and 18 genera. However, Mamaev [28] considered that Unnithan's work could result in additional confusion, and rejected all Unnithan's subfamilies, recognising only five of his 13 new genera. This rearrangement was revised

*Corresponding author: $\mathrm{yk} \_1256 @ 163$. com again by Mamaev [29], who proposed eight subfamilies and 39 genera. Several genera were subsequently added to the family, such as Neobivaginopsis Villalba, 1987, Tinrovia Mamaev, 1987, Serranicotyle Maillard, Euzet \& Silan, 1988, Sciaenacotyle Mamaev, 1989, Synocoelicotyloides Mamaev \& Brashovian, 1989, Paranaella Kohn, Baptista-Farias \& Cohen, 2000 and Omanicotyle Yoon, Al-Jufaili, Freeman, Bron, Paladini \& Shinn, 2013 [14, 20, 27, 30, 39]. Several new species of Microcotylidae have recently been described [2, 4-6, 8, 13, 21]. At present, the Microcotylidae includes more than 200 species in 53 genera [37], 29 species in 13 genera are known from China [40, 42].

Coral reefs are well known for their remarkable biodiversity. Many monogenean species have been described from 
the coral reefs of the Hawaiian Islands, the Great Barrier Reef, and New Caledonia [17, 18, 35, 38]. The Nansha Islands of the South China Sea are a typical coral reef ecosystem, from which numerous coral reel fishes have been recorded [25]. However, the diversity of monogeneans in this region is poorly known. During an ongoing investigation of the monogenean fauna from the South China Sea, specimens of an undescribed species of Microcotylidae were collected from the Yongshu Reef. The morphological features of this new species are described herein, and a new genus is proposed to accommodate this new species.

\section{Materials and methods}

\section{Specimen collection and morphological analysis}

Fishes were caught by line angling off the Yongshu Reef in the South China Sea from March to May, 2016. Parasites were collected and treated as described by Zhang et al. [41]. Twelve parasitic specimens were preserved in $70 \%$ ethanol for subsequent staining with acetic carmine, four were mounted in Berlese fluid for the morphological study of the hard parts, and two were digested with proteinase $\mathrm{K}(20 \mu \mathrm{g} / \mu \mathrm{L})$ for $30 \mathrm{~min}$ at room temperature for the analysis of genital spines. The remaining specimens were fixed in $95 \%$ ethanol for DNA extraction. Illustrations were drawn with the help of an Olympus LB (Olympus Corporation, Japan), scanned, and processed with Photoshop CS4.0 (Adobe, USA). Specimens were measured using Olympus DP22 software. All measurement ranges are given in micrometres, followed by the mean and the number of specimens studied $(n)$ in parentheses. The method for measurement of genital atrium spines is shown in Figure 1.

\section{Sequences of monogeneans}

Total genomic DNA was extracted using the TIANamp Marine Animals DNA Kit (Tiangen, China), following the manufacturer's instructions. We amplified the C1-D2 fragment of the $28 \mathrm{~S}$ ribosome RNA subunit with PCR using previously published primer pairs (C1F: 5' - ACCCGCTGAATTTAAGCAT $-3^{\prime}$ and D2R: $5^{\prime}$ - TGGTCCGTGTTTCAAGAC $-3^{\prime}$ ) [11]. Each $25 \mu \mathrm{L}$ PCR contained $12.5 \mu \mathrm{L}$ Master Mix (2x),

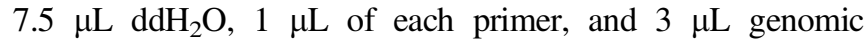
DNA. The PCR cycling conditions were initial denaturation at $94{ }^{\circ} \mathrm{C}$ for $5 \mathrm{~min}$; followed by 35 cycles of $94{ }^{\circ} \mathrm{C}$ for $1 \mathrm{~min}, 56{ }^{\circ} \mathrm{C}$ for $45 \mathrm{~s}$, and $72{ }^{\circ} \mathrm{C}$ for $1 \mathrm{~min}$; and a final elongation at $72{ }^{\circ} \mathrm{C}$ for $10 \mathrm{~min}$. PCR products were confirmed by $1 \%$ agarose gel electrophoresis, and sequenced by the Sangon Biotech Company (Guangzhou, China). The sequences obtained were analyzed using DNAMAN 7.0 and Sequencher 5.0 (Gene Codes Corp.) software, compared to the GenBank database content with BLAST, and deposited in GenBank under accession number MH700264, with a final length of $881 \mathrm{bp}$.

\section{Trees of monogeneans and distances}

A tree was constructed from our new sequence of Paracaesicola nanshaensis $\mathrm{n}$. sp. and $28 \mathrm{~S}$ sequences of microcotylids

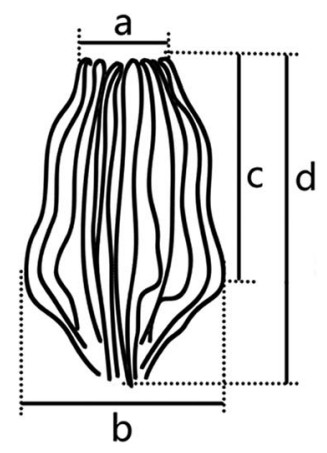

Figure 1. Method of measurements of genital atrium spines.

available in GenBank; a sequence of Polystomoides asiaticus Rohde, 1965 was used as the outgroup. The dataset included 29 nucleotide sequences (Table 1). There were 855 positions in the dataset (including gaps). After estimating the best model with MEGA7 [22], the tree was inferred using the maximum likelihood (ML) method based on the general time reversible model with gamma distribution (GTR + G) in MEGA7 [31], with 1000 replications. The neighbour-joining (NJ) method was also used for comparison in MEGA7. Distances between sequences (Kimura-2 parameter distances) were computed from the same dataset with MEGA7 [19].

\section{Results \\ Molecular analyses}

The partial 28S rDNA gene sequence of Paracaesicola nanshaensis $\mathrm{n}$. sp. was aligned with 28 other monogenean sequences, including 19 microcotylid sequences. There was a total of 855 positions in the final dataset, including 381 conserved sites, 474 variable sites, and 338 parsimony informative sites. The Kimura-2 parameter genetic distances between our new sequences and other microcotylid sequences ranged from $13.6 \%$ to $31.3 \%$ (Table 2). The most closely related species to P. nanshaensis n. sp. were Diplostamenides sciaenae (FJ432589), Diplostamenides sp. (MH700263), and Cynoscionicola branquialis (AF382050), with estimated genetic distances (Kimura 2-parameter) of 13.6\%, 13.8\%, and 14.5\%, respectively.

For trees, the neighbour-joining and maximum likelihood methods led to slightly different topologies. Here we present only the ML tree with Bootstrap support values at nodes (Fig. 2). The topology of the ML showed representative species belonging to different families (Microcotylidae, Heteraxinidae, Gotocotylidae, Protomicrocotylidae, Allodiscotylidae), while forming a monophyletic clade in their own family. Within the microcotylid clade, the new species $P$. nanshaensis clustered with Cynoscionicola branquialis AF382050 and Diplostamenides sciaenae FJ432589 to form a separate monophyletic subclade (68\% bootstrap support in ML, $76 \%$ in NJ). However, members of Microcotylinae do not form an exclusive clade in their own subfamily. The molecular phylogenetic results supported $P$. nanshaensis n. sp. as a new taxon. 
Table 1. Species of the monogeneans used in the molecular analysis.

\begin{tabular}{|c|c|c|c|c|}
\hline Parasite & Host & Location & Accession no. & Reference \\
\hline Paracaesicola nanshaensis $\mathrm{n} . \mathrm{sp}$. & Paracaesio sordidus (Abe et Shinohara) & China & MH700264 & Present study \\
\hline $\begin{array}{l}\text { Diplostamenides sciaenae (Goto, 1894) } \\
\quad \text { Mamaev, } 1986\end{array}$ & - & China & FJ432589 & Direct submission \\
\hline Diplostamenides sp. & Johnius belangerii (Cuvier) & China & MH700263 & Direct submission \\
\hline Cynoscionicola branquialis & Umbrina xanti Gill & Mexico & AF382050 & {$[32]$} \\
\hline $\begin{array}{l}\text { Microcotyle erythrini Van Beneden \& } \\
\text { Hesse, } 1863\end{array}$ & Pagellus erythrinus (Linnaeus) & France & AM157221 & [3] \\
\hline Microcotyle arripis Sandars, 1945 & Arripis georgianus (Valenciennes) & Australia & GU263830 & [7] \\
\hline Microcotyle sebastis Goto, 1894 & Sebastes sp. & UK & AF382051 & {$[32]$} \\
\hline $\begin{array}{l}\text { Omanicotyle heterospina (Mamaev \& } \\
\text { Parukhin, 1974) Yoon, Al-Jufaili, } \\
\text { Freeman, Bron, Paladini \& Shinn, } \\
2013\end{array}$ & Argyrops spinifer (Forsskål) & Oman & JN602095 & {$[39]$} \\
\hline $\begin{array}{l}\text { Sparicotyle chrysophrii (Van Beneden } \\
\text { \& Hesse, 1863) Mamaev, } 1984\end{array}$ & Sparus aurata (Valenciennes) & France & AF311719 & {$[15]$} \\
\hline $\begin{array}{l}\text { Pagellicotyle mormyri (Lorenz, 1878) } \\
\quad \text { Mamaev, } 1984\end{array}$ & Lithognathus mormyrus (Linnaeus) & France & AF311713 & {$[15]$} \\
\hline $\begin{array}{l}\text { Atrispinum acarne Maillard \& Noisy, } \\
\quad 1979\end{array}$ & Pagellus acarne (Risso) & France & AF311702 & {$[15]$} \\
\hline $\begin{array}{l}\text { Bivagina pagrosomi (Murray, 1931) } \\
\quad \text { Dillon \& Hargis, } 1965\end{array}$ & - & - & AJ243678 & Direct submission \\
\hline Metamicrocotyla sp. & Osteomugil ophuyseni (Bleeker) & China & MH700260 & Direct submission \\
\hline Polylabris sillaginae (Woolcock, 1936) & Sillaginodes punctatus (Cuvier) & Australia & GU289509 & [7] \\
\hline Polylabroides sp. & Acanthopagrus schlegelii (Bleeker) & China & MH700258 & Direct submission \\
\hline $\begin{array}{l}\text { Microcotyloides incisa (Linton, 1910) } \\
\text { Fujii, } 1944\end{array}$ & Rhomboplites aurorubens (Cuvier) & USA & KU527427 & [9] \\
\hline $\begin{array}{l}\text { Microcotyloides incisa (Linton, 1910) } \\
\text { Fujii, } 1944\end{array}$ & Lutjanus griseus (Linnaeus) & Mexico & MG586861 & Direct submission \\
\hline Caballeraxine sp. & Leiognathus Equulus (Forsskål) & China & MH700261 & Direct submission \\
\hline Polynemicola sp. & Polynemus sextarius (Bloch \& Schneider) & China & MH700265 & Direct submission \\
\hline $\begin{array}{l}\text { Kahawaia truttae (Dillon et Hargis, } \\
\text { 1965) Lebedev, } 1969\end{array}$ & Arripis truttacea (Forster) & Australia & GU263831 & {$[7]$} \\
\hline $\begin{array}{l}\text { Probursata brasiliensis Takemoto, } \\
\text { Amato \& Luque, } 1993\end{array}$ & Oligoplites sp. & Brazil & AF382049 & {$[32]$} \\
\hline $\begin{array}{l}\text { Cemocotyle carangis (MacCallum, } \\
\text { 1913) Sproston, } 1946\end{array}$ & Caranx latus Agassiz & - & MG984598 & Direct submission \\
\hline $\begin{array}{l}\text { Gotocotyla bivaginalis (Ramalingam, } \\
\text { 1961) Rohde, } 1976\end{array}$ & Scomberomorus commerson (Lacepède) & Australia & AF382039 & [32] \\
\hline Gotocotyla secunda (Tripathi, 1954) & Scomberomorus commerson (Lacepède) & Australia & AF382040 & [32] \\
\hline $\begin{array}{l}\text { Neomicrocotyle pacifica (Meserve, } \\
\text { 1938) Yamaguti, } 1968\end{array}$ & Caranx hippos (Linnaeus) & Mexico & AF382043 & [32] \\
\hline $\begin{array}{l}\text { Bilaterocotyloides carangis } \\
\quad \text { Ramalingam, } 1961\end{array}$ & - & India & KF804032 & Direct submission \\
\hline $\begin{array}{l}\text { Metacamopia oligoplites Takemoto, } \\
\text { Amato \& Luque, } 1996\end{array}$ & Oligoplites sp. & Brazil & AF382038 & {$[32]$} \\
\hline $\begin{array}{l}\text { Allodiscocotyla diacanthi Unnithan, } \\
\quad 1962\end{array}$ & - & India & KF804033 & Direct submission \\
\hline Polystomoides asiaticus Rohde, 1965 & Cuora amboinensis (Daudin) & - & Z83008 & [24] \\
\hline
\end{tabular}


Table 2. Distances between microcotylid taxa (Kimura-2 parameter model), shown as percentages.

\begin{tabular}{|c|c|c|c|c|c|c|c|c|c|c|c|c|c|c|c|c|c|c|c|}
\hline & 1 & 2 & 3 & 4 & 5 & 6 & 7 & 8 & 9 & 10 & 11 & 12 & 13 & 14 & 15 & 16 & 17 & 18 & 19 \\
\hline 2 & 14.5 & & & & & & & & & & & & & & & & & & \\
\hline 3 & 13.8 & 6.7 & & & & & & & & & & & & & & & & & \\
\hline 4 & 13.6 & 7.4 & 1.1 & & & & & & & & & & & & & & & & \\
\hline 5 & 15.8 & 12.5 & 13.2 & 13.2 & & & & & & & & & & & & & & & \\
\hline 6 & 16.2 & 12.8 & 13.6 & 13.5 & 0.2 & & & & & & & & & & & & & & \\
\hline 7 & 17.0 & 13.3 & 14.2 & 14.2 & 0.6 & 0.9 & & & & & & & & & & & & & \\
\hline 8 & 15.5 & 12.7 & 14.5 & 14.1 & 5.1 & 5.4 & 5.8 & & & & & & & & & & & & \\
\hline 9 & 15.0 & 14.8 & 13.2 & 13.9 & 9.9 & 10.2 & 10.9 & 11.8 & & & & & & & & & & & \\
\hline 10 & 16.9 & 13.6 & 14.3 & 14.1 & 5.2 & 5.5 & 6.0 & 5.1 & 12.1 & & & & & & & & & & \\
\hline 11 & 20.8 & 15.8 & 19.0 & 19.4 & 14.9 & 15.4 & 15.8 & 14.1 & 16.6 & 15.1 & & & & & & & & & \\
\hline 12 & 19.2 & 14.3 & 17.5 & 17.9 & 13.8 & 14.2 & 14.5 & 13.4 & 15.7 & 14.7 & 1.0 & & & & & & & & \\
\hline 13 & 31.3 & 28.8 & 29.3 & 29.9 & 26.7 & 27.2 & 27.3 & 28.5 & 29.3 & 30.5 & 31.3 & 28.1 & & & & & & & \\
\hline 14 & 21.9 & 15.5 & 18.7 & 18.7 & 9.7 & 10.3 & 11.2 & 11.5 & 16.0 & 13.8 & 20.0 & 20.0 & 50.3 & & & & & & \\
\hline 15 & 21.8 & 15.8 & 20.0 & 20.0 & 8.6 & 9.1 & 9.9 & 9.8 & 14.4 & 11.9 & 17.2 & 17.4 & 52.2 & 3.5 & & & & & \\
\hline 16 & 21.4 & 11.3 & 16.0 & 16.0 & 9.6 & 10.2 & 11.1 & 12.5 & 15.1 & 13.1 & 19.2 & 19.2 & 45.8 & 6.9 & 7.3 & & & & \\
\hline 17 & 16.4 & 13.5 & 15.0 & 15.5 & 13.7 & 14.1 & 14.3 & 14.7 & 14.5 & 15.9 & 16.0 & 15.4 & 26.9 & 17.4 & 18.1 & 15.8 & & & \\
\hline 18 & 17.9 & 16.6 & 16.6 & 16.8 & 12.0 & 12.0 & 13.2 & 12.4 & 13.7 & 15.0 & 17.3 & 16.7 & 29.8 & 18.7 & 17.2 & 18.6 & 13.6 & & \\
\hline 19 & 20.2 & 14.9 & 16.3 & 16.5 & 14.3 & 14.7 & 15.5 & 15.2 & 16.0 & 16.9 & 16.5 & 15.5 & 26.7 & 22.5 & 20.3 & 19.6 & 17.0 & 17.8 & \\
\hline 20 & 19.5 & 15.1 & 16.0 & 15.8 & 12.2 & 12.5 & 13.3 & 13.1 & 14.8 & 14.7 & 15.6 & 14.9 & 26.8 & 19.4 & 16.7 & 18.1 & 14.9 & 15.0 & 5.3 \\
\hline
\end{tabular}

Appellations of 20 taxa are stated below. 1 Paracaesicola nanshaensis (MH700264), 2 Cynoscionicola branquialis (AF382050), 3 Diplostamenides sp. (MH700263), 4 Diplostamenides sciaenae (FJ432589), 5 Microcotyle sebastis (AF382051), 6 Microcotyle erythrini (AM157221), 7 Microcotyle arripis (GU263830), 8 Omanicotyle heterospina (JN602095), 9 Kahawaia truttae (GU263831), 10 Bivagina pagrosomi (AJ243678), 11 Microcotyloides incisa (KU527427), 12 Microcotyloides incisa (MG586861), 13 Polynemicola sp. (MH700265), 14 Sparicotyle chrysophrii (AF311719), 15 Pagellicotyle mormyri (AF311713), 16 Atrispinum acarne (AF311702), 17 Metamicrocotyla sp. (MH700260), 18 Caballeraxine sp. (MH700261), 19 Polylabris sillaginae (GU289509), 20 Polylabroides sp. (MH700258).

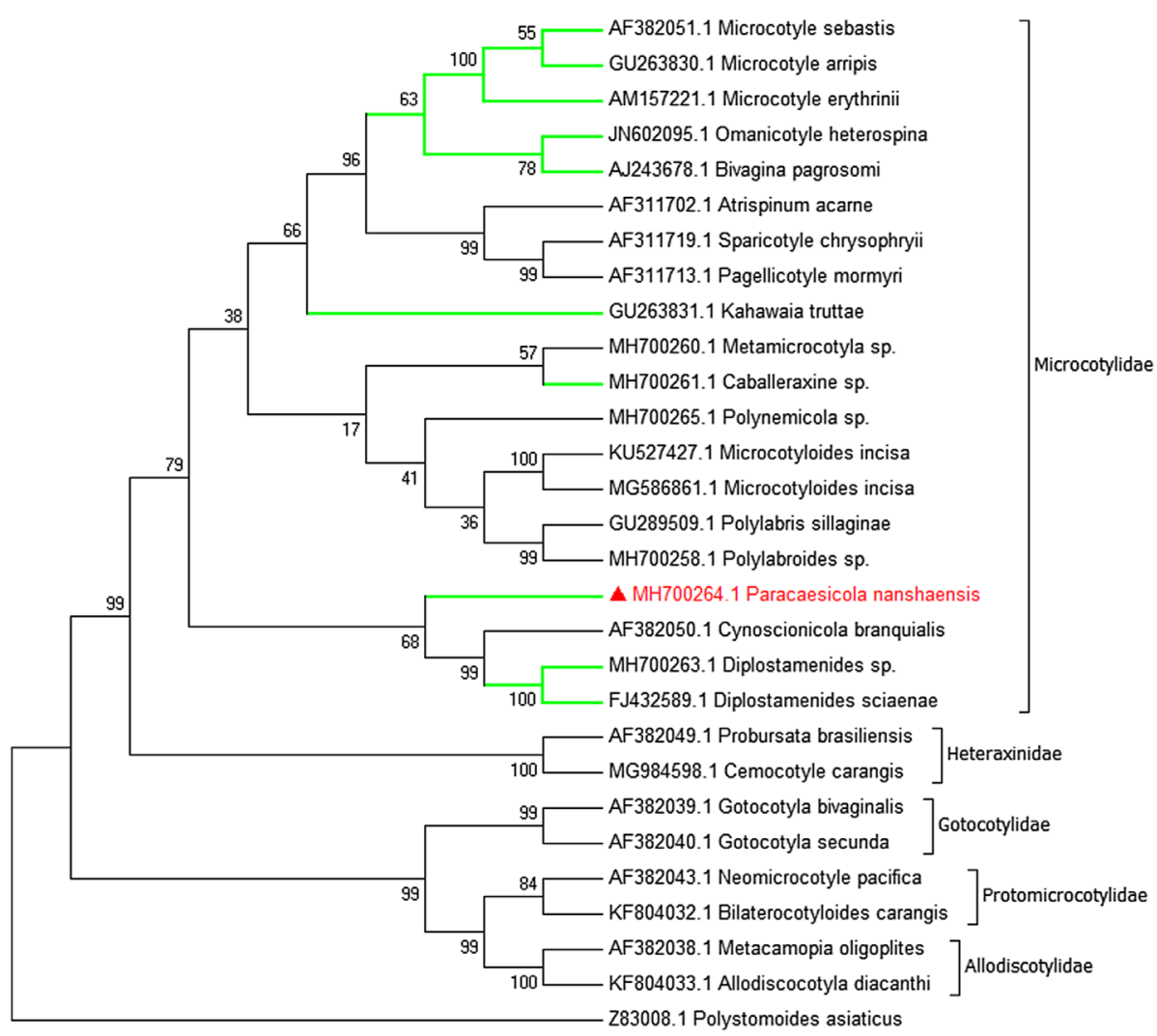

Figure 2. Maximum likelihood tree of the Microcotylidae based on an analysis of 28S rDNA sequences. Bootstrap percentages with 1000 replicates. The new species is in red colour and the branches of representative species in Microcotylinae are in green. 


\section{Paracaesicola n. gen.}

urn:Isid:zoobank.org:act:B25B37E4-A32D-4952-A5B9-

\section{F249CB1FE2CD}

Class: Monogenea Carus, 1863

Family: Microcotylidae Taschenberg, 1879

Subfamily: Microcotylinae Monticelli, 1892

Diagnosis: Body, bottle-shaped. Haptor, short, inverted triangle. Clamps of microcotylid type, arranged in two equal rows. Anchors and haptoral lappet absent. Pair of buccal suckers, septate, and muscular. Oesophagus without diverticula. Intestine extending into haptor, but not confluent posteriorly. Testes arranged in two longitudinal rows and extending into the haptor. Vas deferens, a sinuous tube, arising medially from testes and terminating in a muscular male copulatory organ (MCO). MCO sausage shaped, entirely unarmed. Genital atrium armed with a crown of robust, equal-sized spines, clustered together and standing vertically on top of MCO. Single vagina well visible, bottle-shaped, immediately posterior to $\mathrm{MCO}$; vaginal pore middorsal; vaginal atrium, distinctly bulbous, armed with a small tuft of spines at the posterior end. Eggs oval, with a long coiled polar filament posteriorly. Parasitic on gills of Perciform fishes.

Type-species: Paracaesicola nanshaensis n. sp.

Etymology: The name refers to the host Paracaesio sordidus.

\section{Paracaesicola nanshaensis n. sp.}

urn:1sid:zoobank.org:act:9279425B-6E9A-4BD4-92C18D86144A72FE

Type-host: Paracaesio sordida Abe \& Shinohara, 1962.

Type-locality: Yongshu Reef $\left(112^{\circ} 58^{\prime}-112^{\circ} 96^{\prime} \mathrm{N}, 9^{\circ} 37^{\prime}-\right.$ $9^{\circ} 61^{\prime}$ E,), South China Sea (12 April 2016).

Site on the host: Gill.

Prevalence and intensity: Three fish were examined and all were infected. We identified 21 worms across all examined fish.

Type-material: Holotype (No. NSYS2016041201) and paratypes (Nos. NSYS2016041202-12) deposited in the Fish Parasite Laboratory, College of Life Science, South China Normal University, Guangzhou, China. Two paratypes (NHMUK No. 2019.10.30.1-2) deposited in the Natural History Museum, London (NHMUK).

Etymology: The species is named after the locality, the Nansha Islands in the South China Sea.

\section{Description (Figs. 3 and 4)}

(Based on 13 whole-mounted worms). Body bottle-shaped, tapering gradually from vagina towards anterior end (Figs. 3A and 4A). Body length 1986-3616 $(2964, n=13)$, body width at level of ovary $320-716(495, n=13)$. One median and two lateral head glands (Fig. 4E). Paired muscular buccal suckers with septa, each sucker 38-79 $(50, n=13)$ long and 78-127 $(103, n=13)$ wide. Pharynx spherical, 30-61 (47, $n=9)$ long and $31-48(40, n=9)$ wide, immediately posterior to buccal suckers. Oesophagus simple, without diverticula, bifurcating into two intestinal caeca at genital atrium. Intestinal caeca with lateral branches, extending into haptor, not confluent posteriorly. Haptor shaped as an inverted equilateral triangle,
613-1109 $(822, n=13)$ long and 481-1082 $(755, n=13)$ wide, bearing 55-65 $(60, n=13)$ clamps, arranged symmetrically in two bilateral rows. Clamps microcotylid type, each 30-58 (44, $n=22)$ long and 46-93 $(67, n=22)$ wide, similar in shape, with middle clamps slightly larger. Each clamp consisting of two posterolateral sclerites, two anterolateral sclerites with foot-like proximal end, and one midsclerite with dorsal and ventral Y-shaped terminations (Figs. 3D and 4F). Haptoral lappet and anchors absent. Testes $16-25(20, n=5)$ in number, in two roughly alternating longitudinal rows and extending into haptor (Fig. 3A), normally irregular, but presenting as a long strip in contracted samples (Fig. 3F). Testicular region 497990 (785, $n=11)$ long, approximately one fourth of body length. Vas deferens, a sinuous tube, passing medially from testes to male copulatory organ (MCO). MCO conspicuous, well-muscled, cylindrical, unarmed, 89-150 (121, $n=12)$ long, 47-77 $(58, n=12)$ wide (Figs. $3 \mathrm{C}_{1}$ and $\left.4 \mathrm{~B}\right)$. Genital atrium $179-423(327, n=16)$ from anterior extremity of body, armed with crown of 16 robust closely packed genital spines (Fig. $4 \mathrm{C}_{1}$ ); Genital spines located immediately anterior to MCO, but not extending into MCO (Figs. $3 \mathrm{C}_{1}$ and $4 \mathrm{~B}$ ), with measurements as shown in Figure 1: (a) 19-31 (23, $n=20)$; (b) 49-62 (55, $n=20)$; (c) 54-68 (61, $n=20)$; (d) 72-93 $(84, n=20)$; Each spine blade shaped in lateral view and bow-like in outline, with obvious arch at the proximal third of total length, gradually narrowing anteriorly and sharply posteriorly (Figs. $3 \mathrm{C}_{2}$ and $4 \mathrm{C}_{2}$ ). Ovary pretesticular, resembling a question mark (Fig. 3F). Vitelline reservoir Y-shaped. Vitellarium coextensive with intestinal caeca. Single vagina well visible, immediately posterior to MCO, bottle-shaped (Figs. 3B, 4B, and 4D); vaginal pore opening middorsally; vaginal atrium oval with a hardened, muscular shell, 106-131 (116, $n=12)$ long, 67-103 $(84, n=12)$ wide, armed with a small tuft of irregular spines at the posterior end. Occasionally, a long bag-shaped muscular canal linked to posterior vaginal atrium. Uterus a slender tube, extended anteriorly into genital atrium. Genitointestinal canal visible in some specimens, enters right intestinal caecum (Fig. 3F); oviduct, oötype not observed; precise junctions between vitelline reservoir, ovary, uterus, and genitointestinal canal not elucidated. Eggs oval, 107-167 (134, $n=12)$ long and $45-103(76, n=12)$ wide, with two filaments; anterior one short, posterior one very long and coiled (Fig. 3E).

\section{Differential diagnosis}

Based on the revision of Mamaev [29], we here assign the new species to the Microcotylinae by the following morphological features: a symmetrical haptor with microcotylid-type clamps, armed genital atrium, intestinal caeca unfused posteriorly, absence of terminal lappet and anchors, a pretesticular ovary in the form of a question mark, numerous testes, a single middorsal vagina. The new genus is erected herein primarily on the basis of the morphological features of terminal structures of the reproductive system: the sausage-shaped muscular MCO, the armed genital atrium, and the bottle-shaped vagina with distinctly bulbous vaginal atrium.

As suggested by Yoon et al. [39], genera within Microcotylinae can be distinguished by the number of vaginal openings, armature of the vagina, and of the male terminal. Among 

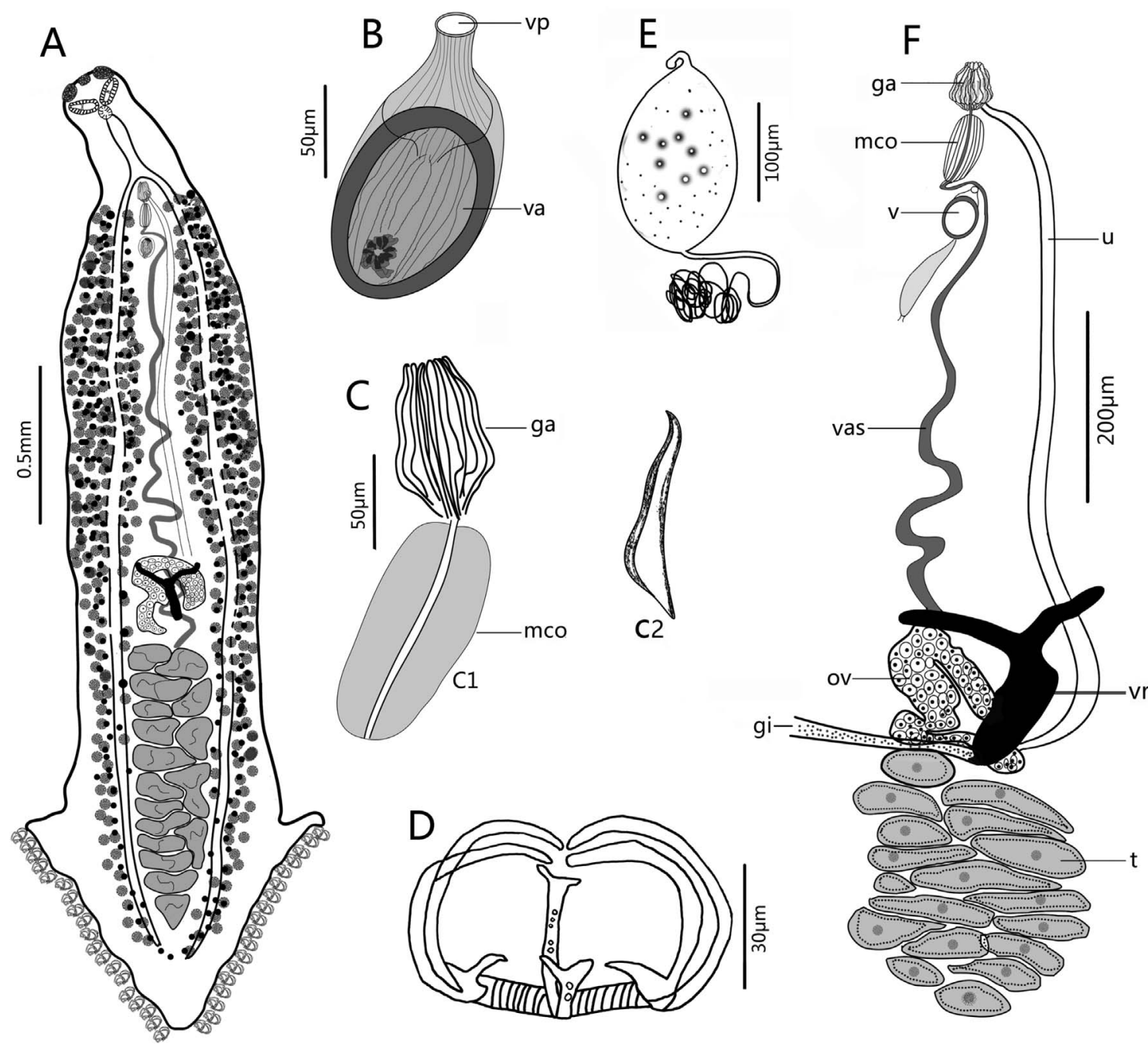

Figure 3. Paracaesicola nanshaensis n. gen., n. sp. from Paracaesio sordida. (A) holotype, whole body (ventral view); (B) vagina (vp, vaginal pore; va, vaginal atrium); $(C)$ male terminal $\left(\mathrm{C}_{1}\right.$, genital atrial spines and male copulatory organ; $\mathrm{C}_{2}$, a single spine in lateral view); (D) clamp; (E) egg; (F) reproductive systems (ga, genital atrial spines; mco, male copulatory organ; v, vagina; vas, vas deferens; ov, ovary; t, testes; vr, vitelline reservoir; gi, genitointestinal canal; u, uterus). B-F are paratypes.

Microcotylinae, Paracaesicola n. gen. most closely resembles Atriostella Unnithan, 1971 as indicated by the armed genital atrium and unarmed MCO [39]. However, it can be distinguished from it by the haptor, the MCO, and genital spines [34]. The haptor of species of Atriostella spp. is slender taillike, slightly less than half total body length, the genital atrium is armed with usually long spines of dissimilar lengths, and the cirrus is roughly spheroidal with lobes. Moreover, the vagina of Atriostella spp. is unarmed. All these features are highly dissimilar to those in the new species described.

\section{Discussion}

Within Microcotylidae, the armatures of male and female terminalia are complex and diverse. Paracaesicola nanshaensis n. g. n. sp. is characterised by its sausage-shaped muscular male copulatory organ (MCO) and bottle-shaped vagina. Except for species in Microcotyloides Fujii, 1940 and Polynemicola Unnithan, 1971, the MCOs of most microcotylid species are conical in shape, bulbous, or not differentiated [9, 29]. In addition, the unique arrangement of the genital spines, MCO, and vagina in $P$. nanshaensis n. sp. (closely clustered in a line, such that the vagina is located immediately posterior to the MCO, and the MCO is also immediately posterior to the genital spines) and the disposition of genital atrium spines (tightly gathered and standing vertically on top of the MCO) are not seen in the other microcotylid species (Fig. 4B). Moreover, in $P$. nanshaensis, testes extend well into the haptor. In all other microcotylid species with a separate haptor, there is little to no overlap between the haptor and the testicular field $[23,36]$. Morphological characters are, however, often affected by sampling and fixation conditions, as has been observed in studies of other species of Platyhelminthes [1, 2]. Here, the samples placed directly in alcohol exhibited a strong contraction of the body, causing the testes to transform from a normal 


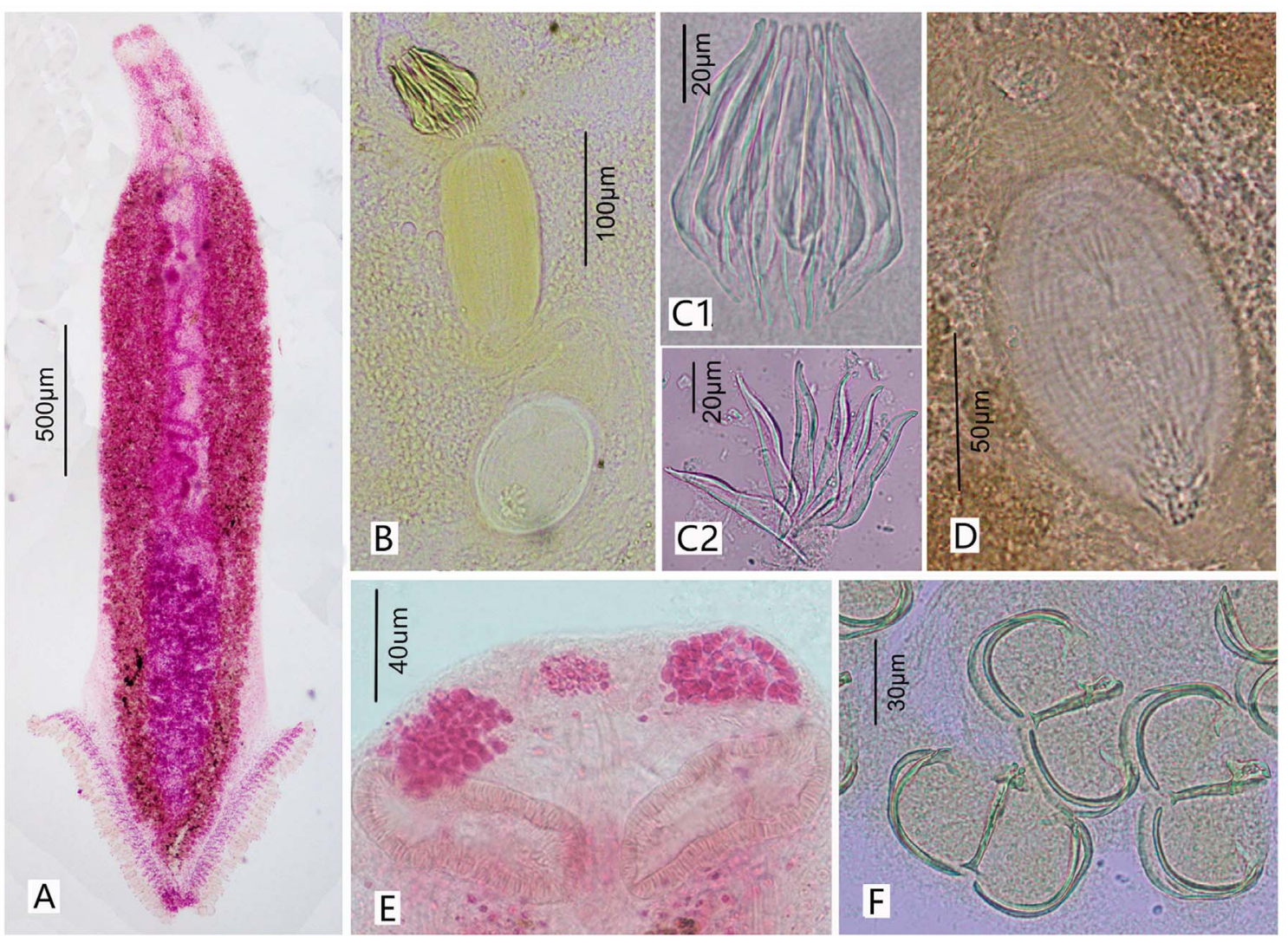

Figure 4. Photographs of Paracaesicola nanshaensis n. gen., n. sp. (A) holotype, whole worm (ventral view); (B) the terminal of the reproductive system; $(C)$ genital atrium $\left(\mathrm{C}_{1}\right.$ shows intact genital spines; $\mathrm{C}_{2}$ shows individual spines, as separated by protease $\left.\mathrm{K}\right)$; (D) vagina; (E) head glands and buccal suckers; (F) clamps. B-F are paratypes.

follicular shape into a long transverse strip. Machkewskyi et al. [26] identified seven measurements in microcotylids as independent of body length: pharynx length, genital atrium length, vitello-vaginal duct length, number of testes, number of clamps, length of the clamps, and width of clamp. The size of the haptor is determined by the number and the size of clamps. In $P$. nanshaensis, the haptor bears relatively few clamps (55-65). As a consequence, the haptor of $P$. nanshaensis is short and presents as an inverted equilateral triangle. Some microcotylid species have approximately the same or fewer clamps, as compared to P. nanshaensis (e.g., some species in Metamicrocotyla Yamaguti, 1953, Microcotyle Van Beneden \& Hesse, 1863, Polylabris Euzet \& Cauwet, 1967 and Solostamenides Unnithan, 1971) [2, 12, 21, 36]. However, the number of clamps in microcotylids varies greatly, even within the same genus.

The erection of this new genus was further supported by our molecular phylogeny, which placed $P$. nanshaensis in the microcotylid clade, but with a high genetic difference from all other ingroup microcotylids. Our phylogenetic topology was congruent with previous phylogenetic studies that recovered Omanicotyle heterospina grouping with Bivagina pagrosomi, and further forming a clade with Microcotyle spp. $[16,32,39]$. This clade has a relatively close relationship with species in the subfamily Atriasterinae (Sparicotyle Mamaev, 1984, Pagellicotyle Mamaev, 1984 and Atrispinum Euzet \& Maillard, 1974) [15]. However, Paracaesicola nanshaensis do not share a recent common ancestor with other members of Microcotylinae. Additionally, other members of the subfamily Microcotylinae do not form an exclusive clade. Diplostamenides Unnithan, 1971 and Caballeraxine Lebedev, 1972 (Microcotylinae), for example, group with Cynoscionicola Price, 1962 (Anchoromicrocotylinae Bravo-Hollis, 1981) and Metamicrocotyla (Metamicrocotylinae Yamaguti, 1963), respectively. This result suggests that the Microcotylinae maybe require division into smaller subfamilies. The phylogeny of the Microcotylidae is not well resolved, because the bootstrap values in some branches are low. Owing to the paucity of molecular sequences for species in the Microcotylidae, it is difficult to accurately determine phylogenetic relationships within its families. Therefore, sequence data for additional taxa are required.

Acknowledgements. This work was supported by the National Natural Science Fund of China (No. 31572232) and Guangdong MEPP Fund (No. GDOE (2019) A23). We are grateful to Professor Jianying Zhang for the literature provided. We thank LetPub (https:// www.letpub.com) for its linguistic assistance during the preparation of this manuscript.

\section{Conflict of interest}

The authors declare that they have no conflict of interest. 


\section{References}

1. Ahuir-Baraja AE, Padrós F, Palacios-Abella JF, Raga JA, Montero FE. 2015. Accacoelium contortum (Trematoda: Accacoeliidae) a trematode living as a monogenean: morphological and pathological implications. Parasite Vector, 8, 540.

2. Ayadi ZEM, Gey D, Justine JL, Tazerouti F. 2017. A new species of Microcotyle (monogenea: Microcotylidae) from Scorpaena notata (Teleostei: Scorpaenidae) in the Mediterranean Sea. Parasitology International, 66(2), 37-42.

3. Badets M, Whittington I, Lalubin F, Allienne JF, Maspimby JL, Bentz S, Du Preez LH, Barton D, Hasegawa H, Tandon V, Imkongwapang R, Ohler A, Combes C, Verneau O. 2011. Correlating early evolution of parasitic platyhelminths to Gondwana breakup. Systematic Biology, 60(6), 762-781.

4. Bouguerche C, Gey D, Justine JL, Tazerouti F. 2019. Microcotyle visa n. sp. (Monogenea: Microcotylidae), a gill parasite of Pagrus caeruleostictus (Valenciennes) (Teleostei: Sparidae) off the Algerian coast, Western Mediterranean. Systematic Parasitology, 96(2), 131-147.

5. Bouguerche C, Gey D, Justine JL, Tazerouti F. 2019. Towards the resolution of the Microcotyle erythrini species complex: description of Microcotyle isyebi n. sp. (Monogenea, Microcotylidae) from Boops boops (Teleostei, Sparidae) off the Algerian coast. Parasitology Research, 118(5), 1417-1428.

6. Cantatore DMP, Lanfranchi AL, Timi JT. 2011. Pauciconfibula patagonensis sp. nov. (Monogenea: Microcotylidae) parasitizing the horsefish, Congiopodus peruvianus (Pisces: Congiopodidae), from the Patagonian Shelf, Argentina. Memórias do Instituto Oswaldo Cruz, 106(3), 335-338.

7. Catalano SR, Hutson KS, Ratcliff RM, Whittington ID. 2010. Redescriptions of two species of microcotylid monogeneans from three arripid hosts in southern Australian waters. Systematic Parasitology, 76(3), 211-222.

8. Chero JD, Cruces CL, Saez G, Luque JL. 2017. Three monogeneans parasitic on marine sciaenid fish from Peru including description of Cynoscionicola veranoi $\mathrm{n}$. $\mathrm{sp}$. (Microcotylidae), and redescription of C. americanus Tantaleán, Martínez and Escalante, 1987 and Hargicotyle sciaenae Oliva and Luque, 1989 (Diclidophoridae). Acta Parasitologica, 62(3), $675-687$.

9. Claxton AT, Fuehring AD, Andres MJ, Moncrief TD, Curran SS. 2017. Parasites of the Vermilion Snapper, Rhomboplites aurorubens (Cuvier), from the Western Atlantic Ocean. Comparative Parasitology, 84(1), 1-14.

10. Dillon WA, Hargis WJ. 1965. Monogenetic trematodes from the Southern Pacific Ocean. 2. Polyopisthocotyleids from New Zealand fishes: the families Discocotylidae, Microcotylidae, Axinidae and Gastrocotylidae. Biology of the Antarctic Seas II, Antarctic Research Series, 5, 251-280.

11. Hassouna N, Mithot B, Bachellerie JP. 1984. The complete nucleotide sequence of mouse 28S rRNA gene. Implications for the process of size increase of the large subunit rRNA in higher eukaryotes. Nucleic Acids Research, 12(8), 3563-3583.

12. Hayward CJ. 1996. Revision of monogenean genus Polyabris (Microcotylidae). Invertebrate Taxonomy, 10(5), 995-1037.

13. Isbert W, Carrassón M, Pérez-del-Olmo A, Montero FE. 2017. A new species of Tinrovia Mamaev, 1987 (Monogenea: Microcotylidae) from the deep-sea fish Notacanthus bonaparte Risso (Notacanthiformes: Notacanthidae) in the Western Mediterranean and the North East Atlantic. Systematic Parasitology, 94(5), 609-619.

14. Jones MES, Gibson DI. 1999. A list of old and recently erected monogenean genus-group names not included in Yamaguti's Systema helminthum. Systematic Parasitology, 16(3), 213-226.
15. Jovelin R, Justine JL. 2001. Phylogenetic relationships within the polyopisthocotylean monogeneans (Platyhelminthes) inferred from partial 28S rDNA sequences. International Journal for Parasitology, 31(4), 393-401.

16. Jun JW. 2015. Phylogenetic study on Microcotyle sp. (Monogenea) from common dentex (Dentex dentex) in the Mediterranean Sea, Greece. African Journal of Biotechnology, 14(33), 2532-2538.

17. Justine JL. 2007. Parasite biodiversity in a coral reef fish: twelve species of monogeneans on the gills of the grouper Epinephelus maculatus (Perciformes: Serranidae) off New Caledonia, with a description of eight new species of Pseudorhabdosynochus (Monogenea: Diplectanidae). Systematic Parasitology, 66(2), 81-129.

18. Justine JL. 2010. Parasites of coral reef fish: how much do we know? With a bibliography of fish parasites in New Caledonia. Belglan Journal of Zoology, 140(3), 155-190.

19. Kimura M. 1980. A simple method for estimating evolutionary rates of base substitutions through comparative studies of nucleotide sequences. Journal of Molecular Evolution, 16, $111-120$

20. Kohn A, Baptista-Farias MDD, Cohen SC. 2000. Paranaella luquei gen. et sp. n. (Monogenea: Microcotylidae), a new parasite of Brazilian catfishes. Folia Parasitologica, 47(4), 279-283.

21. Kritsky DC, Oktener A. 2015. Solostamenides paucitesticulatus $n$. sp. (Monogenoidea: Mazocraeidea: Microcotylidae) from the freshwater mullet Liza abu (Heckel) (Mugiliformes: Mugilidae) from Ataturk Reservoir on the Euphrates River in southern Turkey. Systematic Parasitology, 91(2), 139-145.

22. Kumar S, Stecher G, Tamura K. 2016. MEGA7: molecular evolutionary genetics analysis version 7.0 for bigger datasets. Molecular Biology and Evolution, 33(7), 1870-1874.

23. Lebedev BI, Parukhin AM, Roitman V. 1970. Monogeneans Oligonchoinea (Monogenoidea)-parasites of carangid fishes of North Vietnam Bay. Biologiya Morya, 20, 167-186. (in Russian).

24. Littlewood DTJ, Rohde K, Clough KA. 1997. Parasite speciation within or between host species? - Phylogenetic evidence from site-specific polystome monogeneans. International Journal for Parasitology, 27(11), 1289-1297.

25. Ma CH, You K, Zhang MZ, Li FQ, Chen DG. 2008. A preliminary study on the diversity of fish species and marine fish faunas of the South China Sea. Journal of Ocean University of China, 7(2), 210-214.

26. Machkewskyi VK, Dmitrieva EV, Al-Jufaili S, Al-Mazrooei NA. 2013. Microcotyle omanae $\mathrm{n}$. sp. (Monogenea: Microcotylidae), a parasite of Cheimerius nufar (Valenciennes) (Sparidae) from the Arabian Sea. Systematic Parasitology, 86(2), 153-163.

27. Maillard C, Euzet L, Silan P. 1988. Creation of the genus Serranicotyle (Monogenea, Microcotylidae): Serranicotyle labracis (Van Beneden et Hesse, 1863) n. comb., ectoparasite of Dicentrachus labrax (Teleostei). Annales De Parasitologie Humaine Et Comparée, 63, 33-36.

28. Mamaev YL. 1977. On one classification of monogeneans of the family Microcotylidae. Parazitologiya, 11, 98-103. (in Russian).

29. Mamaev YL. 1986. The taxonomical composition of the family Microcotylidae Taschenberg, 1879 (Monogenea). Folia Parasitologica, 33(3), 199-206.

30. Mamaev YL, Brashovian PP. 1989. Syncoelicotyloides macruri gen et sp nov, the first member of the subfamily Syncoelicotylinae Microcotylidae, Monogenea from Macrouriformes. Parazitologiya, 23(6), 532-536. (in Russian).

31. Nei M, Kumar S. 2000. Molecular Evolution and Phylogenetics. New York: Oxford University Press. 
32. Olson PD, Littlewood DTJ. 2002. Phylogenetics of the Monogenea-evidence from a medley of molecules. International Journal for Parasitology, 32(3), 233-244.

33. Tripathi YR. 1956. Studies on the parasites of Indian fishes. IV. Trematoda: Monogenea. Microcotylidae. Records of the Indian Museum, 52, 231-247.

34. Unnithan RV. 1971. On the Functional Morphology of a New Fauna of Monogenoidea on Fishes from Trivandrum and environs. Part IV. Microcotylidae sensu stricto and its repartition into subsidiary taxa. American Midland Naturalist, 85, 366-398.

35. Whittington ID. 1998. Diversity "down under": monogeneans in the Antipodes (Australia) with a prediction of monogenean biodiversity worldwide. International Journal for Parasitology, 28(10), 1481-1493.

36. Williams A. 1991. Monogeneans of the families Microcotylidae Taschenberg, 1879 and Heteraxinidae Price, 1962 from Western Australia, including the description of Polylabris sandarsae n. sp. (Microcotylidae). Systematic Parasitology, 18(1), 17-43.
37. Worms R. 1879. Microcotylidae Taschenberg. Accessed at: http://www.marinespecies.org/aphia.php?p=taxdetails\&id=119247 on 2020-01-16.

38. Yamaguti S. 1968. Monogenetic Trematodes of Hawaiian Fishes. Honolulu: University of Hawaii Press. p. 287.

39. Yoon GH, AlJufaili S, Freeman MA, Bron JE, Paladini G, Shinn AP. 2013. Omanicotyle heterospina n. gen. et n. comb. (Monogenea: Microcotylidae) from the gills of Argyrops spinifer (Forsskål) (Teleostei: Sparidae) from the Sea of Oman. Parasite Vector, 6(1), 170.

40. Zhang JY, Yang TB. 2001. Monogenea of Chinese marine fishes. XIV. Two new species of Microcotylidae from fishes of the South China Sea. Systematic Parasitology, 48(1), 67-73.

41. Zhang JY, Liu L, Ding XJ. 1997. Monogenea of Chinese marine fishes. VII. A new species and two new records of the Tetraonchoididae from fishes of the South China and East China Seas. Systematic Parasitology, 38(3), 197-201.

42. Zhang JY, Yang TB, Liu L, Ding XJ. 2003. A list of monogeneans from Chinese marine fishes. Systematic Parasitology, 54(2), 111-130.

Cite this article as: Zhou Z-H, Li Y-Z, Liu L, Ding X-J \& Yuan K. 2020. Paracaesicola nanshaensis n. gen., n. sp. (Monogenea, Microcotylidae) a gill parasite of Paracaesio sordida (Teleostei, Lutjanidae) from the South China Sea. Parasite 27, 33.

O PARASTE

An international open-access, peer-reviewed, online journal publishing high quality papers on all aspects of human and animal parasitology

Reviews, articles and short notes may be submitted. Fields include, but are not limited to: general, medical and veterinary parasitology; morphology, including ultrastructure; parasite systematics, including entomology, acarology, helminthology and protistology, and molecular analyses; molecular biology and biochemistry; immunology of parasitic diseases; host-parasite relationships; ecology and life history of parasites; epidemiology; therapeutics; new diagnostic tools.

All papers in Parasite are published in English. Manuscripts should have a broad interest and must not have been published or submitted elsewhere. No limit is imposed on the length of manuscripts.

Parasite (open-access) continues Parasite (print and online editions, 1994-2012) and Annales de Parasitologie Humaine et Comparée (1923-1993) and is the official journal of the Société Française de Parasitologie. 